the authors suggest that the creature's ancestors evolved primarily on land.

Curr. Biol. http://doi.org/sjf (2014)

\section{ECOLOGY}

\section{Chernobyl birds} adapt to radiation

Researchers studying birds near the Chernobyl nuclear-disaster site in Ukraine have found the first evidence of wild animals adapting to ionizing radiation.

Ismael Galván, now at the

Doñana Biological Station

in Seville, Spain, and his

colleagues examined feather and blood samples from 16 bird species, including barn swallows (Hirundo rustica) and wood warblers (Phylloscopus sibilatrix), in and around the Chernobyl exclusion zone.

They found that birds from more-contaminated areas had higher levels of antioxidants — which mop up damaging free radicals produced by radiation exposure - than birds from areas that were less contaminated. Animals from high-radiation regions also had better body condition and showed decreased DNA damage and oxidative stress. Funct. Ecol. http://doi.org/sh7 (2014) \section{MATERIALS \\ Electronics mould to body tissue}

Shape-shifting polymers could one day be used in implantable electronic sensors that conform to tissue inside the body.

A team led by Takao Someya at the University of Tokyo attached organic thin-film transistors to polymers that deform when warmed. They first fabricated the device in the shape of a helix and then flattened it. When they applied

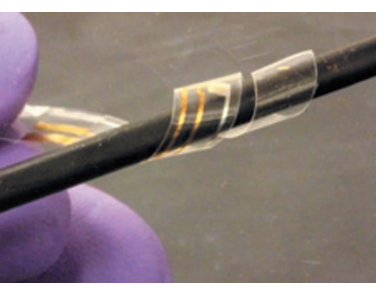

heat, the device wrapped itself around a thin cylinder (pictured). Under the skin of a rat, the film softened to follow the contours of the tissue 24 hours after implantation, while still maintaining its electronic properties.

The authors say that their system offers advantages over other materials: stiff substances cannot move with the body and elastic materials are difficult to insert in vivo and hard to produce in bulk.

Adv. Mater. http://doi.org/sg7 (2014)

$$
\text { MICROBIOLOGY }
$$

\section{Immune system boosts microbe}

A protein secreted by human immune cells prompts an infectious bacterium to mutate, protecting it from drugs and immune attack.

Pseudomonas aeruginosa is a leading cause of fatal lung infections in people with cystic fibrosis (CF). A team led by Daniel Wozniak of Ohio State University in Columbus found that LL-37, a human protein produced by immune cells called neutrophils, triggered the bacteria to make a sticky, sugary coating that is often seen in chronic infections of P. aeruginosa.

At low levels, LL-37 entered bacterial cells and bound to their DNA. By disrupting DNA replication, the protein induced mutations that boosted production of the sugar coating and resistance to the antibiotic rifampin. The mutations were similar to those seen in $P$. aeruginosa isolated from people with CF. PLoS Pathog. 10, e1004083 (2014) \section{GENOMICS \\ Genome of the tsetse fly decoded}

The genome sequence of the disease-carrying tsetse fly reveals potential targets for fly-control measures to stop the spread of disease.

Tsetse flies are the sole carriers of a protozoan

SOCIAL SELECTION

\title{
US research censure stirs up Twitter
}

The US biomedical-research system is overcrowded, underfunded and headed for decline, according to a muchdiscussed report by four top-tier researchers, including Nobel prizewinner Harold Varmus, director of the US National Cancer Institute. The authors argue that the imbalance between the surge of talented scientists and the steady dwindling of funds for research has created a "hypercompetitive" atmosphere that stifles careers and hinders scientific progress. The paper resonated with young researchers, guaranteeing significant coverage on Twitter. John Bachman, a graduate student in a systems-biology lab at Harvard University, tweeted that the paper was a "must-read".

Proc. Natl Acad. Sci. USA 111, 5773-5777 (2014)

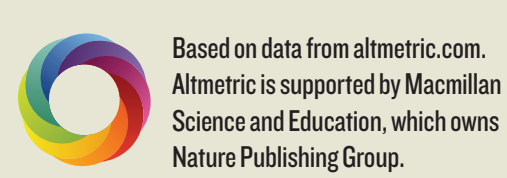

DNATURE.COM

For more on popular papers: go.nature.com/nd3kil parasite that causes trypanosomiasis in humans (known as sleeping sickness) and in livestock throughout sub-Saharan Africa.

Members of the International Glossina Genome Initiative sequenced the DNA of the tsetse fly Glossina morsitans morsitans, which transmits the parasite to livestock. They found genes that are responsible for some of the fly's unique features, such as its ability to produce milk for its offspring and its attraction to the colour blue.

The genomic data could enable researchers to develop methods for manipulating the insect's reproduction, for example, thus helping to control tsetse-fly populations. Science 344, 380-386 (2014) For a longer story on this research, see go.nature.com/yrum $7 w$

\section{Monsoon wet spells get wetter}

The Indian subcontinent has seen greater extremes in rainfall during the South Asian summer monsoon season over the past 30 years than before 1980 .
Nearly $20 \%$ of the world's population is affected by this monsoon, which brings most of India's annual rainfall. Deepti Singh and her colleagues at Stanford University in California compared precipitation data during wet and dry spells in two time periods, 1951-80 and 1981-2011.

Statistical analyses revealed that wet spells have grown more intense during the recent period, and that dry spells have become more frequent. The authors also found increased variability in daily rainfall over the past half-century, and an overall drop in peak-season precipitation.

These changes were associated with shifts in atmospheric circulation patterns and increased moisture availability. The more intense wet spells increase the risk of floods and the more frequent dry spells could negatively affect agriculture, the authors say.

Nature Clim. Change http://dx.doi. org/10.1038/nclimate2208(2014)

\section{$\rightarrow$ NATURE.COM}

For the latest research published by Naturevisit:

www.nature.com/latestresearch 